\title{
Synthesis and Evaluation of Some Novel N, N- Dialkylaminoalkoxy-2-Oxo-Indole-3-Ylidene Benzohydrazides as Anticonvulsant Agents
}

\author{
Sravanthi Madhira ${ }^{\mathrm{a}}$, Kiranmai Mandava ${ }^{\mathrm{a}^{*}}$, Sarangapani Manda ${ }^{\mathrm{b}}$, Sai Prasanna \\ $\mathrm{R}^{\mathrm{a}}$, Vijayalaxmi $\mathrm{T}^{\mathrm{a}}$ \\ ${ }^{a}$ Department of Pharmaceutical Chemistry, Bharat Institute of Technology, Jawaharlal Nehru Technological \\ University, Telangana, India-501510. \\ ${ }^{b}$ Department of Pharmaceutical Chemistry, University College of Pharmaceutical Sciences, Kakatiya \\ University, Telengana, India-506009.
}

\begin{abstract}
A series of N,N-dialkylaminoalkoxy-2-Oxo-indole-3-ylideneBenzohydrazides were synthesized by using the well designed synthetic route and the purity of the compounds were assessed by TLC, and characterized by FT-IR, NMR spectral data. The anti-convulsant activities of the synthesized compounds were evaluated against MES and PTZ induced seizure models in mice. All the test compounds were administered at doses of $50 \mathrm{mg} / \mathrm{kg}$ body weight orally for MES method. The stimulus parameters in mice were $50 \mathrm{~mA}$ in a pulse of $60 \mathrm{~Hz}$ for 200ms. Intraperitonially for a PTZ method from the series of compounds it was noted that compound $\mathrm{N}, \mathrm{N}$-dimethylaminoPropoxy-2-Oxo-5-methyl-3-ylidenebenzo hydrazides(VIIb) protected more than $80 \%$ of the mice against MES and PTZ induced seizures compound VIId, VIIa, VIIe were found to be next in the order of reducing the duration of convulsions in both MES and PTZ methods. Molecular docking studies were also carried out by using windows 2007 using Moe 2008.10 version. The 5HT $T_{2 c}$ mouse receptor was retrieved from the protein data bank and used as target receptor was retrieved from the protein data bank.
\end{abstract}

Keywords: Anticonvulsant activity, Benzo hydrazides, Maximal electroshock, Pentylenetetrazole, 5-HT $2 c$ receptors, Molecular docking studies

\section{Introduction}

Epilepsy is the most common neurological disorder after a migraine, stroke, Alzheimer's disease ${ }^{1}$ affecting 50 million individual worldwide. The average incidence of epilepsy each year in the U.S is estimated as 150,000 or 48 for every 100,000 people $^{2,3}$.The word epilepsy is derived from the Greek word epilambanien meaning to attack or seize. Epilepsy is not a disease, but a syndrome of different cerebral disorders of the central nervous system. This syndrome is charecterised by paroxysomal, excessive, and hypersynchronous discharges of large number of neurons these discharges disrupt normal brain function by creating fluctuations in electrochemical balances ${ }^{4,5}$ epilepsy treatment is still one of the major problems in medicine because of the uncontrolled seizures in some types of epilepsia, toxicity of medication, several side effects of currently used drugs, which may limit their maximal usefulness, obligation of administration of some anti-epileptics used symptomatically in the treatment of epilepsies for a long time even throughout one's life as they have to be used chronically, and also the risk of tolerance developing against the present drugs ${ }^{6,7}$. Although there are a number of antiepileptic drugs available in the market, because of above mentioned reasons, development of new compounds having anticonvulsant activity is still necessary ${ }^{8-11}$

Isatin (1H-indole-2,3-dione,) was first obtained by Erdman and Laurent in 1841 as a product from the oxidation of indigo by nitric and chromic acids ${ }^{13,14}$. Isatin $(1 \mathrm{H}$-indole-2, 3-dione) pharmacophore has attracted and has been attracting much attention from medicinal chemists because of great importance in their biological as well as synthetic approach of medicinal chemistry. The various derivatives of isatin are known to possess range of biological properties including antimicrobial ${ }^{15,16}$, anticancer ${ }^{17}$, antiviral ${ }^{18}$, anticonvulsant ${ }^{19,20}$, antidepressant $^{21}$, anti-inflammatory and analgesic ${ }^{22}$. Surendranath pandeya ${ }^{23,24}$ et al, reported the synthesis and anti-convulsant activity of some novel n-methyl/acetyl, 5-unsubstituted isatin-3- semicarbazones ${ }^{25}$ olesen and kanstrup reported synthesis and anti-convulsant activity of pyrido [2, 3-b] indoles ${ }^{26}$ Evano et al synthesized and reported anti-convulsant activity of $1 \mathrm{H}$-pyrido $[3,4-\mathrm{b}]$ indole-4-carboxamide derivatives ${ }^{27}$. In the last few years, new isatin derivatives have been discovered which show potential hypnotic ${ }^{28}$, anti-bacterial ${ }^{29}$ and MAO inhibitory $^{30}$ activity. Binedaline, amedalin, pindolol, siramesine and oxypertine etc are the marketed drugs bearing indole moiety used against different types of CNS disorders and which encouraged authors to further explore the pharmacological properties of the indole nucleus ${ }^{30}$ Literature survey reveals that benzohydrazide exhibit wide variety of biological activities such as anti-microbial activity ${ }^{31}$, Hypnotic ${ }^{32}$ and anti-convulsant ${ }^{33}$. 
Keeping in view of biological importance of the two molecules, namely isatins with benzohydrazide has been felt worthwhile as depicted in scheme. It is evident from the literature survey that isatin derivatives, and benzo hydrazide derivatives showing more promising effects central nervous system.Keeping in view of these two molecular moieties into a single molecular frame as a model for molecular conjunction by appropriate synthetic routes and to screen them for anti-convulsant activity and neurotoxicity. The objective of the present study was to design a synthetic scheme to carry out molecular conjunction between isatin and benzohydrazide derivatives and to screen the resultant novel derivatives for anticonvulsant activity using in vitro docking and in vivo studies.

\section{Materials And Methods}

The compounds were mostly synthesized by conventional synthetic methods and as described in experimental section and also by the methods established in our laboratory.

2.1Materials: Leptazole, Diazepam, Dialkylaminoalkylhalides Purchased From Sigma Aldrich Chemicals Private Limited, Hyderabad, India, Hydroxyl Amine Hydrochloride,Dry Methanol(HPLC Grade), Hydrazine Hydrate Were Purchased From Merck Chemicals Private Limited Hyderabad ,India

2.2.Chemistry:

All the Solvents employed in the study were dried or distilled before use. Melting points were obtained on a thoshniwall melting point apparatus in open capillary tubes and were uncorrected. The purity of the compounds were ascertained by TLC on silicagel-G plates(merck) Infrared spectra(IR)were recorded with $\mathrm{KBr}$ pellet using Perkin-Elimer BX series, Infrared spectrophotometer, ${ }^{1} \mathrm{H}$-NMR spectra were recorded on Bruckersspectrospin 400mhz spectrophotometer in DMSO-d*

\subsubsection{Synthesis of Indole-2,3-diones(Isatins,III)}

Isatin was synthesised by using sandmayer method and it consists reaction of aniline(I) with chloral hydrate and hydroxylamine hydrochloride in aqueous sodium sulphate to form an isonitrosoacetanilide, which after isolation, when treated with concentrated sulphuric acid, furnishes isatin in $>75 \%$ overall yield $^{34}$

Isonitrosoacetanilides (I1): In a 5lit. RB flask, chloral hydrate $(0.54 \mathrm{M})$ and $1200 \mathrm{~mL}$ of water were placed. To this solution ,crystallized sodium sulphate $(1300 \mathrm{~g})$ was then added followed by a solution of an appropriate aromatic aniline(I) in $300 \mathrm{Ml}$ of water and concentrated hydrochloric acid $(0.52 \mathrm{M})$. Finally, a solution of hydroxylamine $\mathrm{HCl}(1.58 \mathrm{~mol})$ in $500 \mathrm{~mL}$ of water was added. The contents of the flask were heated over a wiregauge by a Mecker burner so that vigorous boiling begins in about 45 minutes. After 1 to 2 minutes of vigorous boiling the reaction was completed. During the heating period itself the crystals of isonitrosoacetanilides started separating out. on cooling under the current of water, the entire product was solidified. It was filtered under suction, air dried, and purified by recrystallization from Methanol(s).

Indole-2,3-diones (III): Sulphuric acid $(600 \mathrm{~g}, \mathrm{~d}, 1.84,326 \mathrm{~mL})$ were warmed at $50^{\circ} \mathrm{C}$ in a one liter RB flask fitted with an efficient mechanical stirrer and to this, finely powdered appropriate isonitrosoacetanilide (II, $0.46 \mathrm{M}$ ) was added at such a rate so as to maintain the temperature between $60^{\circ} \mathrm{C}$ to $70^{\circ} \mathrm{C}$ but not higher. External cooling was applied at this stage so that the reaction could be carried out more rapidly .After the addition of iso nitroso compound the temperature of the solution was raised to $80^{\circ} \mathrm{C}$ and maintained the same for 10 minutes, to complete the reaction. Then the reaction mixture was cooled to room temperature and poured on to crushed ice $(2.5 \mathrm{~kg})$ while stirring. After standing for about half-an-hour, the product separated was filtered, washed several times with small portions of cold water, and dried. Purification of the compound was affected by the recrystallization from methanol.

\subsubsection{Preparation of 4-hyydroxy benzohydrazides $(V)$ :}

In 500ml RBF The mixture of methyl paraben (IV) $(0.02 \mathrm{~mol})$ and hydrazine hydrate $(99 \%),(30 \mathrm{~mL}$, $0.6 \mathrm{~mol}$ ) was refluxed for $12 \mathrm{~h}$. The excess solvent was removed under vacuum up to $10 \mathrm{~mL}$. The reaction mixture was cooled at $4-5^{\circ} \mathrm{C}$. The separated solid crystals (2) were filtered and washed with cold water. The crystals were dried and purified by recrystallization from ethanol (99.9\%). Yield: $90 \%$.M.P. $246-248^{\circ} \mathrm{C}$.

\subsubsection{Preparation of N,N-Dialkyl aminoalkoxy benzohydrazides (VI):}

A mixture of (0.1moles) 4-hydroxy benzohydrazide (V) $(0.12 \mathrm{~mol})$ alkyl halide in $60 \mathrm{ml}$ alcoholic $\mathrm{KOH}$ refluxed for $24 \mathrm{hr}$ at room temperature . the reaction mixture was filtered and filtrate taken into benzene , washed with water and with Hydrochloric acid. combine aqueous acid extracts and were basify with ammonium hydroxide and extracted with chloroform the organic extracts are dried over calcium sulphate and the product recrystallized from ethyl acetate. \%yield:80, melting point: $230-232^{\circ} \mathrm{c}$

\subsubsection{Preparation of N,N-dialkylaminoalkoxy-2-oxo-indole-3-ylidenebenzohydrazides (VII):}

A mixture of an appropriate indole-2,3-dione(III,0.01mol.) Dialkyl aminoalkoxy benzohydrazides (IV, $0.01 \mathrm{~mol}$.) In dry methanol (50ml) was heated under reflux for $30 \mathrm{~min}$. mixture was filtered and dried and purified by methanol.

The physical data of the compounds were presented in table-1. 
<smiles>[H][Y]([H])N[R]Oc1ccc(C(=O)N/N=C2\C(=O)Nc3cc[R]cc32)cc1</smiles>

TABLE 1: Physical data of the N,N-dialkylaminoalkoxy-2-oxo-indole-3-ylidenebenzohydrazides

\begin{tabular}{|l|l|l|l|l|l|l|l|l|}
\hline S.NO. & Compound & $\mathrm{R}$ & $\mathrm{R}^{\prime} \mathrm{R}^{\prime \prime}$ & $\mathrm{R} " '$ & $\mathrm{Mol}$. Formula & Mol.Wt & $\mathrm{M} . \mathrm{p}\left({ }^{\circ} \mathrm{c}\right)$ & $\%$ yield \\
\hline 1 & VII & $-\mathrm{H}$ & $-\mathrm{CH}_{3}$ & Ethyl & $\mathrm{C}_{19} \mathrm{H}_{20} \mathrm{~N}_{4} \mathrm{O}_{3}$ & 352.4 & $272-274$ & 81 \\
\hline 2 & VIIa & $-\mathrm{H}$ & $-\mathrm{CH}_{3}$ & Propyl & $\mathrm{C}_{20} \mathrm{H}_{22} \mathrm{~N}_{4} \mathrm{O}_{3}$ & 366.47 & $280-282$ & 82 \\
\hline 3 & VIIb & $-\mathrm{CH}_{3}$ & $-\mathrm{CH}_{3}$ & Propyl & $\mathrm{C}_{21} \mathrm{H}_{24} \mathrm{~N}_{4} \mathrm{O}_{3}$ & 380.4403 & $284-286$ & 81 \\
\hline 4 & VIIc & $-\mathrm{Cl}$ & $-\mathrm{CH}_{3}$ & Propyl & $\mathrm{C}_{20} \mathrm{H}_{21} \mathrm{ClN}_{4} \mathrm{O}_{3}$ & 400.8587 & $262-264$ & 80 \\
\hline 5 & VIId & $-\mathrm{Br}$ & $-\mathrm{CH}_{3}$ & Propyl & $\mathrm{C}_{20} \mathrm{H}_{21} \mathrm{BrN}_{4} \mathrm{O}_{3}$ & 430.27 & $236-238$ & 85 \\
\hline 6 & VIIe & $-\mathrm{F}$ & $-\mathrm{CH}_{3}$ & Propyl & $\mathrm{C}_{20} \mathrm{H}_{21} \mathrm{FN}_{4} \mathrm{O}_{3}$ & 384.1 & $232-234$ & 75 \\
\hline 7 & VIIf & $-\mathrm{H}$ & $-\mathrm{CH}_{3}$ & Isopropyl & $\mathrm{C}_{20} \mathrm{H}_{22} \mathrm{~N}_{4} \mathrm{O}_{3}$ & 366.47 & $280-282$ & 80 \\
\hline 8 & VIIg & $-\mathrm{CH}$ & $-\mathrm{CH}_{3}$ & Isopropyl & $\mathrm{C}_{21} \mathrm{H}_{24} \mathrm{~N}_{4} \mathrm{O}_{3}$ & 380.44 & $252-254$ & 83 \\
\hline 9 & VIIh & $-\mathrm{Cl}$ & $-\mathrm{CH}_{3}$ & Isopropyl & $\mathrm{C}_{20} \mathrm{H}_{21} \mathrm{ClN}_{4} \mathrm{O}_{3}$ & 400 & $242-246$ & 82 \\
\hline 10 & VIIi & $-\mathrm{Br}$ & $-\mathrm{CH}_{3}$ & Isopropyl & $\mathrm{C}_{20} \mathrm{H}_{21} \mathrm{BrN}_{4} \mathrm{O}_{3}$ & 430 & $278-280$ & 81 \\
\hline 11 & VIIj & $-\mathrm{F}$ & $-\mathrm{CH}_{3}$ & Isopropyl & $\mathrm{C}_{20} \mathrm{H}_{21} \mathrm{FN}_{4} \mathrm{O}_{3}$ & 384 & $236-238$ & 81 \\
\hline
\end{tabular}<smiles>Nc1ccc(P)cc1</smiles><smiles>[3H]C</smiles><smiles>O=C(/C=N\O)Nc1ccc(P)cc1</smiles><smiles>[3H]C</smiles><smiles>O=C1Nc2ccc(P)cc2C1=O</smiles><smiles>COC(=O)c1ccc(O)cc1</smiles><smiles>NNC(=O)c1ccc(O)cc1</smiles><smiles></smiles><smiles>CC(C)C</smiles><smiles>[R]c1ccc2c(c1)/C(=N/NC(=O)c1ccc(O[14NH][1H])cc1)C(=O)N2</smiles>

Isatin Derivatives :

VIIa : R-H, R', R"-CH $\mathrm{CH}_{3}, \mathrm{R}$ '"- Propyl

VIIb : R-CH $\mathrm{CH}_{3}, \mathrm{R}^{\prime}, \mathrm{R}^{\prime \prime}-\mathrm{CH}_{3}, \mathrm{R}$ '"'- Propyl

VIIc: R-Cl, R', R"- $\mathrm{CH}_{3}, \mathrm{R}^{\prime \prime}$ - Propyl

VIId : R-Br, R', R"--CH $\mathrm{CH}_{3}, \mathrm{R}$ '"- Propyl

VIIe : R-F, R',R"- $\mathrm{CH}_{3}, \mathrm{R}^{\prime \prime \prime}-$ Propyl
VIIf : R-H, R',R"- $\mathrm{CH}_{3}, \mathrm{R}$ '"' - Isopropyl VIIg : R- $\mathrm{CH}_{3}, \mathrm{R}, \mathrm{R}$ "- $\mathrm{CH}_{3}, \mathrm{R}$ '"' - Isopropyl

VIIh : R-Cl, R', R"- $\mathrm{CH}_{3}, \mathrm{R}$ '"- Isopropyl

VIII : R-Br, R',R"-CH 3 , R"'- Isopropyl

VIIj : R-F, R',R"-CH 3 , R'"- Isopropyl

Scheme 1: Schematic steps of N,N-dialkylaminoalkoxy-2-oxo-indole-3-ylidenebenzohydrazides 


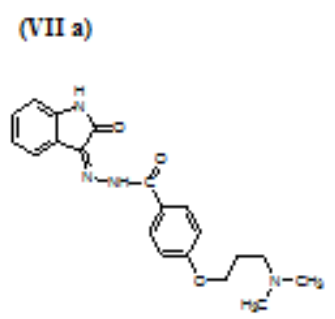

(VII b)

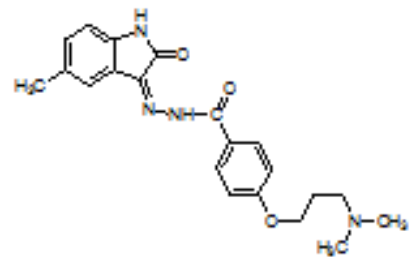

(VII c)

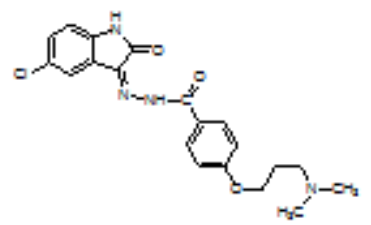

(VIId)

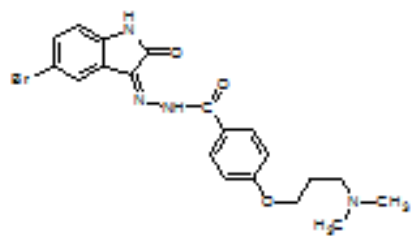

(VII e)

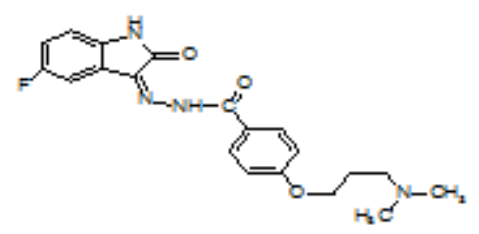

(Z)-4-(3-(dimethylamino) propoxy)-N-(2-oxoindolin-3-ylidene) benzohydrazide

(Z)-4-(3-(dimethylamino) propoxy)- $\mathrm{N}^{2}-$ (5-methyl-2oxoindolin-3-ylidene) benzohydrazide
(Z)-4-(3-(dimethylamino) propoxy)-N'-(5-chloro-2oxoindolin-3-ylidene) beuzohydrazide

(Z)-4-[3-[dime thylamino) propary]-N'-[5-floro-2oxoindolin-3-ylidene) benzohydrazide

Figure1: structures of the substituted N,N-dialkylaminoalkoxy-2-oxo-indole-3-ylidenebenzohydrazide

\subsection{Specral data:}

(Z)-4-(3-(dimethylamino) ethooxy)-N'-(5-chloro-2- oxoindolin-3- ylidene)benzohydrazide(VII)

$1 \mathrm{H}$ NMR(300 mHz, DMSO): $\partial[\mathrm{ppm}] ; 2.3\left(\mathrm{~S}, 6 \mathrm{H}-\mathrm{C}_{2} \mathrm{H}_{6}\right), 6.9-7.7(\mathrm{M}, 8 \mathrm{H}, \mathrm{Ar}-\mathrm{H}), 10.5(\mathrm{~S}, 1 \mathrm{H}-\mathrm{CONH})$, and $13.8(\mathrm{~S}$, $1 \mathrm{H}, \mathrm{N}-\mathrm{H}) \quad \mathrm{IR}(\mathrm{Kbr}) \mathrm{cm}^{-1}: \quad 3189(\mathrm{~N}-\mathrm{H}), \quad 1676,1626(\mathrm{C}=\mathrm{O}), 1608(\mathrm{C}=\mathrm{C}), 1537(\mathrm{C}=\mathrm{N}), 1466(\mathrm{C}-\mathrm{H}$ bending $), 1268(\mathrm{C}-$ $\mathrm{O}, \mathrm{Ar}-\mathrm{O}-\mathrm{C})$

(Z)-4-(3-(dimethylamino)propoxy)-N'-(2-oxoindolin-3-ylidene)benzohydrazide (VIIa) :

IR(Kbr) $\mathrm{cm}^{-1}: 3189(\mathrm{~N}-\mathrm{H}), 1676,1626(\mathrm{C}=\mathrm{O}), 1608(\mathrm{C}=\mathrm{C}), 1537(\mathrm{C}=\mathrm{N}), 1466(\mathrm{C}-\mathrm{H}$ bending $), 1268(\mathrm{C}-\mathrm{O}, \mathrm{Ar}-\mathrm{O}-\mathrm{C})$

(Z)-4-(3-(dimethylamino)propoxy)-N'-(5-methyl-2- oxoindolin-3- ylidene)benzohydrazide (VIIb) :

IR(Kbr) $\mathrm{cm}^{-1}: 3186(\mathrm{~N}-\mathrm{H}), 1676,1626(\mathrm{C}=\mathrm{O}), 1603(\mathrm{C}=\mathrm{C}), 1549(\mathrm{C}=\mathrm{N}), 1484(\mathrm{C}-\mathrm{H}$ bending $), 1262(\mathrm{C}-\mathrm{O}, \mathrm{Ar}-\mathrm{O}-\mathrm{C})$

(Z)-4-(3-(dimethylamino)propoxy)- $\mathrm{N}^{\prime}$-(5-chloro-2- oxoindolin-3- ylidene)benzohydrazide (VIIc) : IR(kbr) $\mathrm{cm}^{-1}: 3317,3197(\mathrm{~N}-\mathrm{H}), 1618(\mathrm{C}=\mathrm{O}), 1538(\mathrm{C}=\mathrm{N}), 1467(\mathrm{C}-\mathrm{H}$ bending $), 1278(\mathrm{C}-\mathrm{O}, \mathrm{Ar}-\mathrm{O}-\mathrm{C})$

(Z)-4-(3-(dimethylamino)propoxy)-N'-(5-bromo-2- oxoindolin-3- ylidene)benzohydrazide (VIId) : IR(Kbr) $\mathrm{cm}^{-1}: 3214,3197(\mathrm{~N}-\mathrm{H}), 1684(\mathrm{C}=\mathrm{O}), 1538(\mathrm{C}=\mathrm{N}), 1472(\mathrm{C}-\mathrm{H}$ bending $), 1262(\mathrm{C}-\mathrm{O}, \mathrm{Ar}-\mathrm{O}-\mathrm{C})$

(Z)-4-(3-(dimethylamino)propoxy)-N'-(5-methyl-2- oxoindolin-3- ylidene)benzohydrazide (VIIe) : IR(Kbr) $\mathrm{cm}^{-1}: 3425(\mathrm{~N}-\mathrm{H}), 1597(\mathrm{C}=\mathrm{O}), 1544(\mathrm{C}=\mathrm{N}), 1422(\mathrm{C}-\mathrm{H}$ bending $), 1253(\mathrm{C}-\mathrm{O}, \mathrm{Ar}-\mathrm{O}-\mathrm{C})$ 


\section{Anticonvulsant Activity}

It is evident from the literature that isatins exhibits anti-convulsant, psychotropic and angiogenic, properties therefore, it has been worthwhile to screen the new isatin-benzohydrazide derivatives for CNS activity.All the synthesised isatins were subjected to the fallowing screening tests

\subsection{Acute toxicity:}

Healthy and adult male albino mice weighing between $20-25 \mathrm{~g}$ were used in the investigation. Animals were fasted for $24 \mathrm{hr}$ and divided into groups of six animals each. The test compounds, dissolved in DMSO were administered, orally, at the dose of $5 \mathrm{mg}$ to $300 \mathrm{mg}$ per $\mathrm{kg}(\mathrm{b} . \mathrm{w}$.) The controlled group of animals received only the vehicle(DMSO) the animals were observed for $48 \mathrm{hr}$ from the time of administration of the test compound to record the mortality.

\subsection{Locomotor activity:}

The locomotor activity was studied by using actophotometer, which operates on photoelectric cells, which are connected in circuit with a counter. When a beam of light falling on the photocells is cut of by animals, a count was recorded. Healthy mice weighing between20-25gm were used. Animals were fasted for overnight and divided into groups of six animals each. The test compounds were dissolved in DMSO and administered at a dose of $50 \mathrm{mg} / \mathrm{kg}$ body weight orally and the control group animals received only vehicle (DMSO) the response (counts) was recorded after $60 \mathrm{~min}$. administration of test compound. The animals were placed in actophotometer for $10 \mathrm{~min}$.and scores were recorded(deflections)the results were compared with the control and presented in table-2:

All the test compounds were administered in a dose of $50 \mathrm{mg} / \mathrm{kg}$ (b.wt) i.p. and motor activity in an open field was determined data are expressed as the number of movements per minute(mean) percentage decrease in activity was calculated

Table 2: Readings of actophotometer:

\begin{tabular}{|l|l|l|l|}
\hline Compounds & $\begin{array}{l}\text { Before administration of compound } \\
(10 \mathrm{~min} .)\end{array}$ & $\begin{array}{l}\text { After administration of } \\
\text { compound (10 min.) }\end{array}$ & change in activity \\
\hline VIIa & 462.00 & 185.12 & 59.93 \\
\hline VIIb & 455.62 & 127.29 & 72.00 \\
\hline VIIc & 447.12 & 161.92 & 63.78 \\
\hline VIId & 470.32 & 147.65 & 68.60 \\
\hline VIIe & 210.55 & 52.43 \\
\hline
\end{tabular}

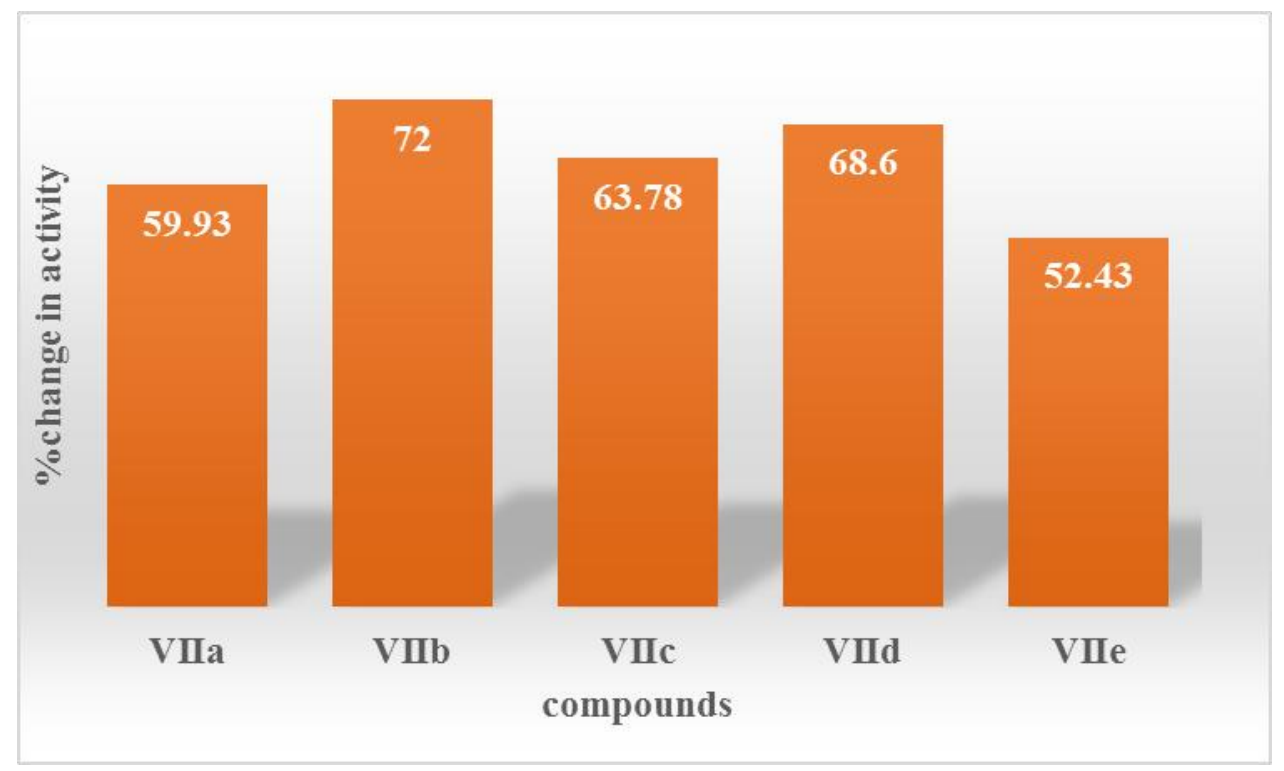

Figure 2: Locomotor activity of isatin derivatives

\subsection{InvivoAnti-Convulsant Activity:}

\subsubsection{Maximal electroshock induced convulsions:}

The anti-convulsant activity was studied by using electroconvulsometer. Healthy male mice weighing between $20-25 \mathrm{gm}$, were fasted for overnight and divided into six groups of six animals each . The test compounds suspended in $0.1 \%$ sodium CMC were administered at a dose of $50 \mathrm{mg} / \mathrm{kg}$ body weight orally. The control group animals received only vehicle (DMSO). The test started $30 \mathrm{~min}$ after oral administration.

DOI: $10.9790 / 3008-1202028493 \quad$ www.iosrjournals.org $\quad 88 \mid$ Page


Maximal seizures were induced by the application of electrical current to the brain via corneal electrodes. The stimulus parameters for mice were $50 \mathrm{~mA}$ in a pulse of $60 \mathrm{~Hz}$ for $200 \mathrm{~ms}$. Abolition of the hind limb tonic extensor spasm was recorded as a measure of anti convulsant activity ${ }^{37,38}$ results are presented in table-3

Table 3: Anti-convulsant activity of N,N-dialkylaminoalkoxy-2-oxo-indole-3-ylidene benzohydrazides against MES-induced convulsions:

\begin{tabular}{|l|l|l|l|}
\hline Compounds & $\begin{array}{l}\text { Substituent } \\
\text { R }\end{array}$ & $\begin{array}{l}\text { Duration of tonic hind limb } \\
\text { extensor phase (in secs.).n=6 }\end{array}$ & $\begin{array}{l}\text { Animals } \\
\text { protected in } \%\end{array}$ \\
\hline VIIa & $\mathrm{H}$ & $37.2 \pm 12$ & 68.7 \\
\hline VIIb & $5-\mathrm{CH}_{3}$ & $24.5 \pm 3$ & 83.19 \\
\hline VIIc & $5-\mathrm{Cl}$ & $29.7 \pm 8$ & 73.40 \\
\hline VIId & $5-\mathrm{Br}$ & $26.2 \pm 6$ & 76.6 \\
\hline VIIl & $5-\mathrm{F}$ & $42.6 \pm 3$ & 61.19 \\
\hline Control & 93.3 & 0 \\
\hline Phenytoin $^{c}$ & 0 & 100 \\
\hline
\end{tabular}

$\mathrm{n}=$ six in each group.

All animals are recovered

The compounds were tested at a dose of $50 \mathrm{mg} / \mathrm{kg}$ (oral)

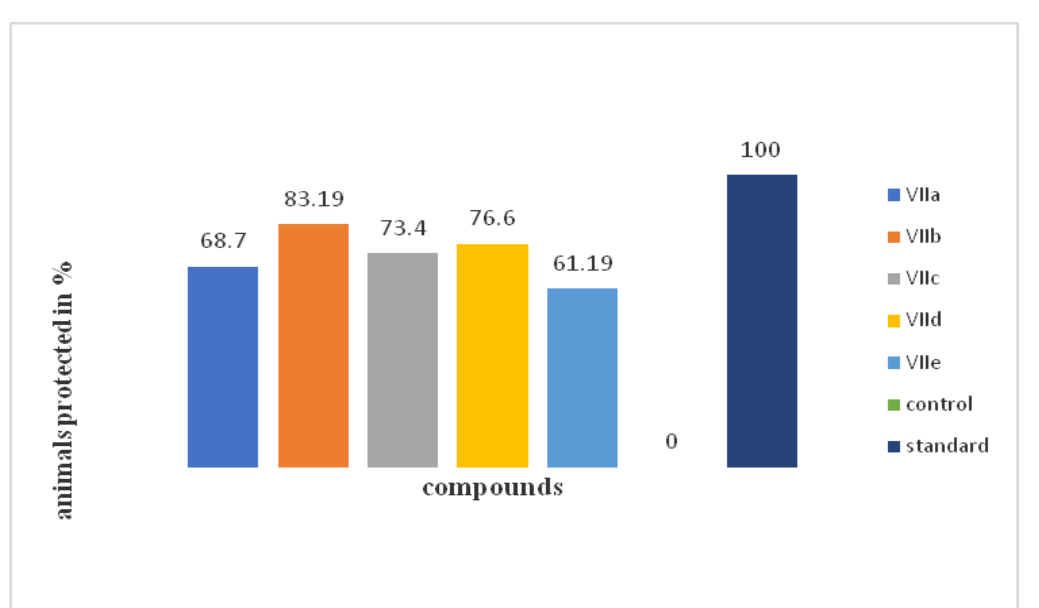

Figure 3: Anticonvulsant activity of N,N-dialkylaminoalkoxy-2-oxo-indole-3-ylidene benzohydrazides against MES-induced convulsions

\subsubsection{Pentylenetetrazole induced convulsions:}

Animals were divided into three groups each comprising of 6 animals in each group one group was used for studying the effects of pentylenetetrazole alone (control) and other groups for studying the protective effect of phenobarbitone(standard) as well as studying the anti-convulsant effect of test compounds. Injected pentylenetetrazole to control and noted the onset of action (indicated by straubs tail, jerky movements of whole body and convulsions ) and severity of convulsions due to the drug.

injected phenobarbitone to second group of animals and test compounds to third group of animals after $30 \mathrm{~min}$. Injected pentylenetetrazole to these animals which received phenobarbitone and test compounds.

Noted either delay or complete abolition of convulsions in mice treated with phenobarbitone and test compounds $^{39}$. And results were presented in table- 4

Table-4 Anticonvulsant activity of N,N-dialkylaminoalkoxy-2-oxo-indole-3-yidene benzohydrazides

\begin{tabular}{|l|l|l|l|}
\hline Compounds & $\begin{array}{l}\text { Substituent } \\
\mathrm{R}\end{array}$ & $\begin{array}{l}\text { Duration of tonic hind limb extensor } \\
\text { phase (in secs.). } \mathrm{n}=6\end{array}$ & Animals protected in \% \\
\hline VIIa & $\mathrm{H}$ & $8.5 \pm 2$ & 70.8 \\
\hline VIIb & $5-\mathrm{CH}_{3}$ & $3.5 \pm 1.2$ & 85.16 \\
\hline VIIc & $5-\mathrm{Cl}$ & $6.6 \pm 2$ & 72.8 \\
\hline VIId & $5-\mathrm{Br}$ & $5.7 \pm 3$ & 78.7 \\
\hline VIIe & $5-\mathrm{F}$ & $8.8 \pm 2.2$ & 68.16 \\
\hline Control & $21.23 \pm 5$ & 0 \\
\hline Phenobarbitone $^{\mathrm{c}}$ & 0 & 100 \\
\hline
\end{tabular}

Alanimals are recovered

The compounds were tested at a dose of $50 \mathrm{mg} / \mathrm{kg}$ (oral) $\mathrm{n}=\mathrm{six}$ in each group. 


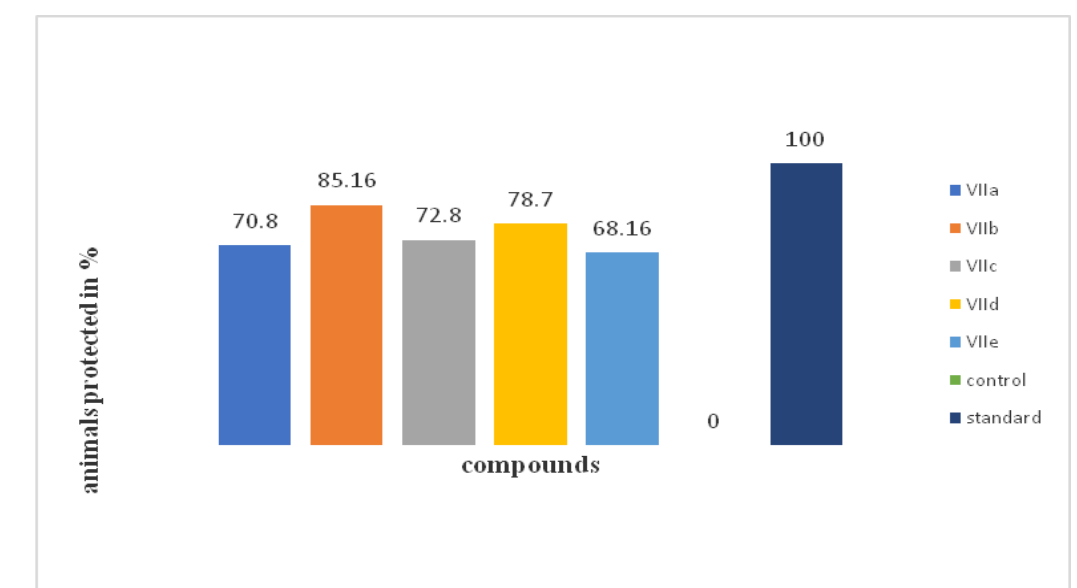

Figure 4: Anticonvulsant activity of N,N-dialkylaminoalkoxy-2-oxo-indole-3-yidene benzohydrazides

\subsection{In vitro studies: Molecular Docking:}

Docking was performed on windows 2007 using MOE 2008.10 version. 5HT2C mouse receptor was retrieved from the protein data bank (PDB code: $2 \mathrm{MHO}$ ) and the enzyme was visualized using sequence option and further co-factors were deleted. The partial charge of the protein was adjusted with the help of force field method AMBER 99. All the synthesised compounds were docked into the 5- $\mathrm{HT}_{2}$ receptor as it is evident from the literature that $5-\mathrm{HT}_{2}$ receptor is one of target for isatins. Docking study results were presented in the table5.Compounds VIIb and VIId showed good docking scores with 5-HT 2 receptor The compounds VIIc, VIIa, VIIe were shown least scores with 5- $\mathrm{HT}_{2}$ receptor.agents. Because of good binding scores 76.9, 27.2 for compound VIIb and 77.2 for compound VIId with Lys-392 receptor residue. Same compounds also showed good invivo activity.And hence compounds VIIb, VIId were considered as good anti-convulsant.

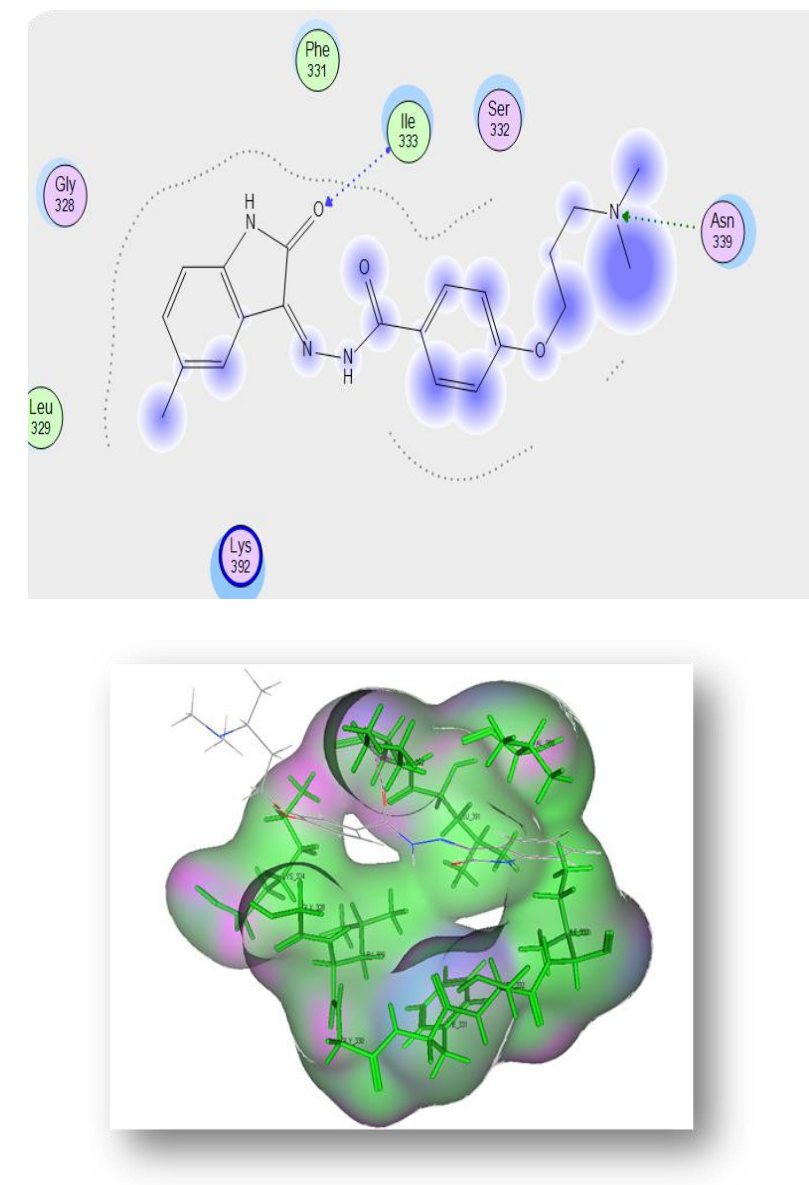

Figure 5: Docking studies of (Z)-4-(3-(dimethylamino)propoxy)-N'-(5-methyl-2- oxoindolin-3- ylidene) benzohydrazide $(\mathrm{VIIb})$ on $5-\mathrm{HT}_{2 \mathrm{C}}$ receptors 
Table: 5 Docking Scores of Compounds With 5-HT 2 receptor

\begin{tabular}{|c|c|c|c|c|c|}
\hline Compounds & Ligand & Receptor Residue & Chain Type & Score & Distance \\
\hline VIIa & $\begin{array}{l}\text { O } 1429 \\
\text { NZ } 1156\end{array}$ & LYS 392 & $\mathrm{H}-\mathrm{acc}$ & $71.3 \%$ & 2.67 \\
\hline \multirow[t]{3}{*}{ VIIlb } & $\begin{array}{ll}\mathrm{H} & 1422 \\
\mathrm{O} & 200 \\
\end{array}$ & LYS 327 & H-don & $20.2 \%$ & 1.98 \\
\hline & $\begin{array}{l}\text { O } 1428 \\
\text { NZ } 1156\end{array}$ & LYS 392 & $\mathrm{H}$-acc & $27.4 \%$ & 3.03 \\
\hline & $\begin{array}{l}\text { O } 1428 \\
\text { NZ } 1156\end{array}$ & LYS 392 & $\mathrm{H}-\mathrm{acc}$ & $76.9 \%$ & 2.44 \\
\hline VIIc & $\begin{array}{l}\text { O } 1428 \\
\text { NZ } 1156 \\
\end{array}$ & LYS 392 & $\mathrm{H}$-acc & $48.1 \%$ & 2.58 \\
\hline \multirow[t]{3}{*}{ VIId } & $\begin{array}{l}\text { H1422 } \\
\text { O } 200\end{array}$ & LYS327 & H-don & $19.3 \%$ & 1.97 \\
\hline & $\begin{array}{l}\text { N1424 } \\
\text { NZ1156 }\end{array}$ & LYS392 & $\mathrm{H}-\mathrm{acc}$ & $26.6 \%$ & 3.06 \\
\hline & $\begin{array}{ll}\mathrm{O} & 1428 \\
\mathrm{NZ1156} & \\
\end{array}$ & LYS392 & $\mathrm{H}$-acc & $77.1 \%$ & 2.44 \\
\hline VIIe & $\begin{array}{l}\text { O } 1423 \\
\text { NZ } 1156\end{array}$ & LYS392 & $\mathrm{H}-\mathrm{acc}$ & $36.0 \%$ & 2.50 \\
\hline
\end{tabular}

\section{Results And Discussions}

Novel isatin derivatives were synthesised by condensation of isatins with alkylated benzohydrazides in the presence of methanol. Details were given in scheme and Structures of all synthesised compounds were given in figure-1, Physical data were shown in table-1.

\subsection{In-vivo anti-convulsant activity:}

All synthesised compounds were evaluated for in-vivo anti-convulsant activity at the dose of $50 \mathrm{mg} / \mathrm{kg}$ by chemically induced convulsions and electrically induced by PTZ method and MES method. From the data it was revealed that all the tested compounds significantly reduced chemically induced convulsions and electrically induced convulsions. And the results were presented in table-3 and 4.Among the tested compounds, VIIb $\left(\mathrm{R}-\mathrm{CH}_{3}\right)$ protected more than $80 \%$ of the mice against MES and PTZ induced convulsions. Compounds VIId,VIIc,VIIa,VIIe were found to be next in the order of reducing the duration of convulsions in both MES and PTZ methods.Interestingly, compounds with electron releasing substituents $\left(\mathrm{R}-\mathrm{CH}_{3}\right)$ at $\mathrm{C}-5$ of isatin nucleus produced $80 \%$ protection against MES and PTZ induced convulsions. Compounds VIIc(R-Cl), VIId(R$\mathrm{Br}$ ), VIId(R-F), VIIe(R-H) exhibited substantial activity with 78.7\%, 72.8\%, 68.9\%, 70.8\%.

Compounds with electron releasing substituents $\left(\mathrm{R}_{-} \mathrm{CH}_{3}\right)$ at $\mathrm{C}-5$ of isatin nucleus produced more anticonvulsant activity. Whereas compounds with electron withdrawing substituents such as (R-Cl, Br, F) at $\mathrm{C}-5$ of isatin nucleus are next in the order of activity.

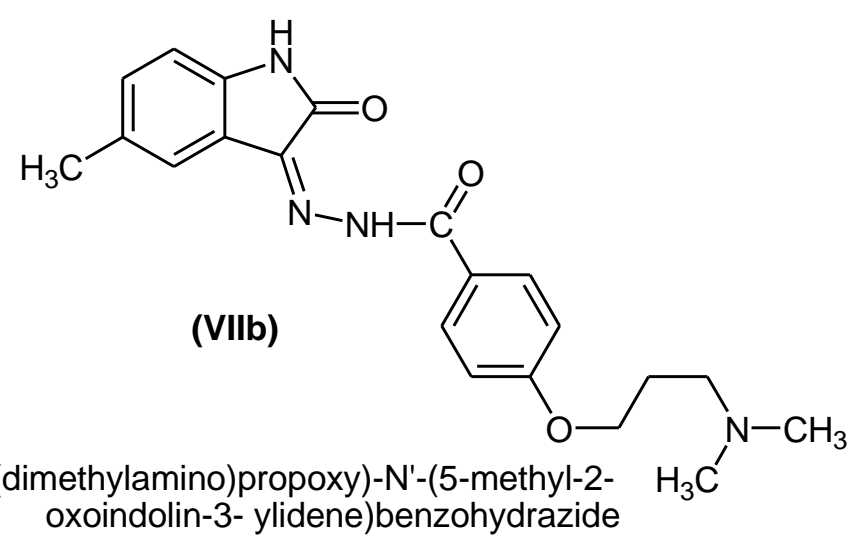

(Z)-4-(3-(dimethylamino)propoxy)-N'-(5-methyl-2-
oxoindolin-3- ylidene)benzohydrazide

\subsection{Docking-studies:}

Docking was performed on windows 2007 using MOE 2008.10 version. 5HT2C mouse receptor was retrieved from the protein data bank (PDB code: $2 \mathrm{MHO}$ ) and the enzyme was visualized using sequence option and further co-factors were deleted. The partial charge of the protein was adjusted with the help of force field method AMBER 99. Later, the protein was subjected to 3D protonation at cut off 12.0, and further hydrogen was added according to standard geometry and the receptor was energy minimized using force field MMFF94x at $0.01 \mathrm{KJ}$ mole gradients. After obtaining docking results, best pose was retained to understand molecular interaction out of 30 poses given for each chemical structure. The resultant best pose score values in the series 
were used for analysis of docking and interaction. All the synthesised compounds were docked into the 5$\mathrm{HT}_{2 \mathrm{c}}$ receptor and the results were presented in the table -5 Compounds VIIb and VIId showed good docking scores with $5-\mathrm{HT}_{2 \mathrm{c}}$ receptor and these compounds also shown good iv-vivo anti-convulsant activity. The compounds VIIc, VIIa, VIIe were shown least scores with 5 - $\mathrm{HT}_{2 \mathrm{c}}$ receptor. Compounds VIIb, VIId are considered as good anti-convulsant agents.

\section{Conclusion}

Present study described the synthesis and characterization of a novel NN-dialkylaminoalkoxy-2-oxoindole-3-ylidene benzohydrazide derivatives. Among the tested compounds, VIIb $\left(\mathrm{R}_{-} \mathrm{CH}_{3}\right)$ has protected more than $80 \%$ of the mice against MES and PTZ induced convulsions. Compounds VIId, VIIc, VIIa and VIIe were found to be next in the order of reducing the duration of convulsions in both MES and PTZ methods. Compounds having electron donating groups at C-5 of isatin nucleus seemed to be necessary in providing higher anticonvulsant activity. Other substituents at various positions are next in the order of activity. It is evident from the anticonvulsant activity that electron donating groups seemed to be necessary moieties in showing higher anticonvulsant activity and in vitro docking studies have confirmed the same.

\section{Acknowledgement}

Authors are thankful to Dr Narendra Sharat Chandra for his guidance and kind support in carrying out docking studies.

\section{References}

[1]. Burger's medicinal chemistry and drug discovery, published by john wiley \& sons. Inc. sixth edition (2003), volume 6: Nervous system agents pp 263-264.

[2]. Joseph I. Sirven, MD | Patricia O. Shafer, RN, MN on 3/2014

[3]. Patricia O. Shafer RN, MN | Joseph I. Sirven, MD on 10/201

[4]. M.Lscheur and T.A pedley,N-Eng.J.Med.,323, 1468,1474(1990). W.loscher.Eur.J.pharma col.342,1-13,(1998).

[5]. Jerome Engel. A Proposed Diagnostic Scheme For People With Epileptic Seizures And With Epilepsy: Report Of The Ilae Task Force On Classification And Terminology. ILAE. Retrieved on 2006-07-18.

[6]. C.Wasterlain in G.siegel G.agarranoff.R.w.Albers,and molinoff, edu,basic neurochemistry,molecular,cellular,medical aspects, $4^{\text {th }}$ edi.,Raven,new York,1989,p.p.797-810.

[7]. M.Dam in D.Schmidt and P.L. Morselli, Eds., Intractable Epilepsy :Experimental and Clinical Aspects, Raven, New York,1986,pp.1-3

[8]. F.E. Dreifussin W.H.Theodore, Ed., Surgical Treatement of Epilepsy, Elsevier, Amsterdam/Newyork,1992,pp.7-11.

[9]. H. Schafer, Handbook of Experimental PharmacologyAntiepileptic Drugs, Springer- verlag Berlin, 1985, pp. 199-210.

[10]. C. O. Wilson, O. Gisvold, R. F. Doerge, Textbook of Organic, Medicinal and Pharmaceutical Chemistry, 7th Ed. Lippincott Co., Philadelphia, 1971

[11]. Houser CR, Esclapez M. Vulnerability and plasticity of the GABA system in the pilocarpine model of spontaneous recurrent seizures. Epilepsy Res. Dec 1996;26(1):207-18. [Medline].

[12]. Solviter RS. Status epilepticus-induced neuronal injury and network reorganization. Epilepsia. 1999; 40(suppl1):S34-9; discussions 40-1. [Medline]

[13]. Scharfman HE, Schwartzkroin PA. Protection of dentate hilar cells from prolonged stimulation by intracellular calcium chelation. Science. Oct 13 1989;246(4927):257-60.[Medline].

[14]. Erdmann, O. L. (1840). "Untersuchungen über den Indigo". Journal für Praktische Chemie. 19(1): $321-$ 362. doi:10.1002/prac. 18400190161

[15]. Laurent, A. (1840). "Recherches sur l'indigo". Annales de Chimie et de Physique. 3 (3): 393-434.R.J Sundberg "The Chemistry of Indoles", Academic, New York, 1975.

[16]. R.J Sundberg "The Chemistry of Indoles", Academic, New York, 1975.

[17]. R. W. Daisley and V. K. Shah, Synthesis and antibacterial activity of some-5-Nitro-3-phenyl imino indole-2-(3H) -ones and their N-Munich bases, J. Pharm. SCI. 73 (1984) 407-411.

[18]. K. Han, Y. Zhou, F. Liu et al., "Design, synthesis and in vitro cytotoxicity evaluation of 5-(2-carboxyethenyl) isatin derivatives as anticancer agents," Bioorganic \& Medicinal Chemistry Letters, Vol. 24, no. 2, pp. 591-594,2014.

[19]. . S. N. Pandeya, D. Sriram, G. Nath and E. De Clercq, Synthesis, antibacterial, antifungal and anti-HIV evaluation of Schiff and Mannich bases of satin derivative with 3-amino-2-methylmercapto quinazolin-4 (3H) -one, Pharm. Acta Helv. 74 (1999) 11-17.

[20]. G. Saravanan, V. Alagarsamy, and P. Dineshkumar,"Anticonvulsantactivityofnovel1-(morpholinomethyl) -3-substitutedisatin derivatives," Bulletin of Faculty of Pharmacy, Cairo University, Vol. 52, no. 1, pp. 115-124,2014.

[21]. S. K. Bhattacharya and A. Chakraborti, Dose related proconvulsant and anticonvulsant activity of isatin, a putative biological factor in rats, Indian. J. Exp. Biol. 36 (1998) 118-121

[22]. C. Radhika, A. Venkatesham, and M. Sarangapani, "Synthesis and antidepressant activity of di substituted-5-aryl-1,2,4-triazoles," Medicinal Chemistry Research, vol. 21, no. 11, pp. 3509-3513,2

[23]. R. Anisetti and M. S. Reddy, "Synthesis, antimicrobial, antiinflammatory and antioxidant activity of novel Spiro (imidazo[4'5':4,5']benzo[1,2-e][1,4]thiazepine)-9,3'--indolines,'JournalofSulfurChemistry,vol.33,no.3,pp.363-372,2012.

[24]. S. N. Pandeya, S. Smitha and J. P. Stables, Anticonvulsant and sedative-hypnotic activities of N-substituted isatin semicarbazones, Arch. Pharm. Pharm. Med. Chem. 4 (2002) 129-134.

[25]. S. N. Pandeya, A. Senthil Raja and J. P. Stables, Synthesis of isatin semicarbazones as novel anticonvulsants - role of hydrogen bonding, J. Pharm. Pharm. Sci. 5 (2002) 266-271.

[26]. S. N. Pandeya, A. K. Agarwal, A. Singh and J. P. Stables, Design and synthesis of semicarbazones and their bio-isosteric analogues as potent anticonvulsant. The role of hydrogen bonding, Acta Pharm. 53 (2003) 15-24.

[27]. H. P. Olesen and A. Kanstrup, Preparation of Pyrido 2,3-b Indoles for Treating a Disease in the CNS via the Metabotropic Glutamate Receptor System, Den. Pat. 97,05,137, 13 Feb 1997; ref. Chem. Abstr. 126 (1997) 212050m.

DOI: 10.9790/3008-1202028493 www.iosrjournals.org $\quad 92 \mid$ Page


[28]. Y. Evanno, L. Dubois, M. Sevrin, F. Marguet, J. Proissant, R. Bartsch and C. Gille, 4-Oxo-3,5- dihydro-4H-pyridazano-4,5-bindole-1-acetamide Derivatives, Their Preparation and their Application in Therapy as GABA Agonists, Fr. Pat. 9,906,406, 11 Feb 1999; ref. Chem. Abstr. 130 (1999) 168385f.

[29]. S. N. Pandeya, S. Smitha and J. P. Stables, Anticonvulsant and sedative-hypnotic activities of N-substituted isatin semicarbazones, Arch. Pharm. Pharm. Med. Chem. 4 (2002) 129-134.

[30]. I. M. Mc Intyre and T. R. Norman, Seratonergic effects of isatin: An endogenous MAO inhibitor related to tribulin, J. Neural Transm. 79 (1990) 35-40.

[31]. Biswal, S.; Sahoo, U.; Sethy, S.; Kumar, H.K.S.; Banerjee, M. Indole: The molecule of diverse biological activities. Asian J.phar.clin.Res. 2012,5,1-6.

[32]. S. Rollas and M. Kiraz, "Synthesis and antimycobacterial activity of some coupling products from 4-aminobenzoic acid hydrazones,"European Journal of MedicinalChemistry,vol.34, no.12,pp.1093-1100,1999

[33]. V.A.Osyanin,P.P.Purygin,andZ.P.Belovsova,"Synthesisof 4-(1H-azol-1-ylmethyl)benzohydrazides and their acyclic and heterocyclicderivatives,"RussianJournalofGeneralChemistry, vol.75,no.1,pp.111-117,2005.

[34]. J.Patole,U.Sandbhor,S.Padhye,D.N.Deobagkar,C.E.Anson, andA.Powell,"Structuralchemistryandinvitroantitubercular activity of acetylpyridine benzoyl hydrazone and its copper complex against Mycobacterium smegmatis," Bioorganic and MedicinalChemistryLetters,vol.13,no.1,pp.51-55,2003.

[35]. Alam, M.; Younas, M.; Zafar, M.A.; Naeem Pak. J. Sci. Ind. Res 1989, 32, 246. (CA 112:7313u)

[36]. G.Henry and A.Blatt,Organic Synthesis Collective, JohnWiley Sons,NewYork,NY,USA,1964.

[37]. Cashin $\mathrm{CH}$,Jackson $\mathrm{H}(1962)$ An apparatus for testing anti-convusant drugs by electroshock seizures in mice, J pharm. Pharmaco $14: 445-475$

[38]. Kitano Y,Usui C, Takasuna K, Hirohashi M, Normura M(1996)Increasing- current electroshock seizures test: a new method for assessment of anti- and pro-convulsant activities of drugs in mice .J Pharmacol Toxicol Meth 35:25-29

[39]. Rastogi SA, Ticku MK (1985) Involvement of a GABAergic mechanism in the anticonvulsant effect of phenobarbital against maximal electro shock- induced seizures in rats, pharmacol Biochem Behav 222:141-146. 